\title{
Haemolytic Effects of Hypo-osmotic Salt Solutions on Human Erythrocytes
}

NEPAL O, ${ }^{1}$ RAO JP²

${ }^{1}$ Department of Physiology

Kathmandu University School of Medical Sciences

Dhulikhel, Kavre

${ }^{2}$ Department of Physiology

Kasturba Medical College

Manipal - 576 104, India

Corresponding Author

Dr Ojashwi Nepal

Department of Physiology

Kathmandu University School of Medical Sciences

Dhulikhel, Kavre

Citation

Nepal O, Rao JP. Haemolytic effects of hypo-osmotic salt solutions on human erythrocytes . Kathmandu Univ med J 2011;34(2):35-9.

\begin{abstract}
Background

While it is well known that hypotonic solutions of sodium chloride induce hemolysis, the effects of other salt solutions on human erythrocytes have not been well documented.

\section{Objective}

The study is to compare the effects of other salt solutions on human red cells.

\section{Methods}

Iso-osmotic and hypo-osmotic solutions of various salts were prepared after taking into account their molecular weight and osmotic pressure. Five healthy volunteers between the age of 22-30 years were randomly selected and ten blood samples were collected from them. The study was conducted from January 2009 to February 2009. Blood was collected from subjects by venepuncture into heparinised tubes. $20 \mu \mathrm{l}$ of blood was pipetted into $1 \mathrm{ml}$ of each solution and incubated for one hour at $37{ }^{\circ} \mathrm{C}$ in a water bath. The solutions were centrifuged and the colour of the supernatant was read in a spectrophotometer. Supernatant from blood added to distilled water was considered $100 \%$ hemolysed.

\section{Results}

Iso-osmotic salt solutions were free of hemolysis. Among chloride salts, sodium chloride showed the least hemolysis and potassium chloride and nickel chloride resulted into greater hemolysis. Among potassium salts, potassium bromate caused highest amount of hemolysis whereas potassium sulphate showed the least.

\section{Conclusion}

The significant differences in hemolytic pattern in hypo-osmotic salts solutions suggest that the hypo-osmotic stress causes morphological changes in red cells that alter their permeability to various ions leading to hemolysis. This probably occurs through opening of volume sensitive channels.

\section{KEY WORDS}

hemolysis, morphological changes, red cells, salt solutions

\section{INTRODUCTION}

A number of investigators have focused their attention on the effects of variations in cell volume on monovalent cation transport across cell membranes. Studies have been carried out on human erythrocytes to examine the alterations of $\mathrm{K}+$ transport induced by swelling the cells by osmotic method in the solutions containing $\mathrm{KCl}$ and $\mathrm{NaCl}^{1,14}$

In order to alter the cell volume, either sucrose (up to $200 \mathrm{mM}$ ) or $\mathrm{NaCl}$ (up to $100 \mathrm{mM}$ ) were added as suspension of cells to prepare anisotonic media to a hypotonic flux medium and the Nystatin method was applied by Kaji. ${ }^{14}$
Red cells have been studied extensively, to determine the permeability across the cell membrane. ${ }^{2-21}$ But, there exists a paucity of information about the effects of altering cell volume in hypotonic salts other than $\mathrm{KCl}$ and $\mathrm{NaCl}$. This study in human red cells by osmotic method compares the effects produced by hypotonic stress in various salt solutions.

In this study we have prepared isotonic solutions of various salts by calculating molecular weights of each salt and by adding half the volume of distilled water, making the salt solutions $50 \%$ osmotic. The human red cells behavior in 
salt solutions other than $\mathrm{NaCl}$ and $\mathrm{KCl}$, provides us with further scientific information, which can be used as a basic tool in a number of studies.

\section{METHODS}

The study was carried out in Kasturba Medical College, Department of Physiology from January to February 2009. Five healthy individuals were bled twice for the study. Subjects were selected by random sampling method, after eliciting history they were examined clinically. Subjects on any kind of medications were excluded from the study. Fresh blood was drawn from the antecubital vein of the volunteers and stored in a heparinised test -tube. $2 \mathrm{ml}$ of fresh sample blood was mixed with heparin $(0.24 \mathrm{ml}$ in $1 \mathrm{ml}$ of blood sample). Biosystem Micropipette of 20 and $500 \mu \mathrm{l}$ were used for pipetting the sample blood and the prepared solutions. The isotonic and hypotonic solutions of nine different salts $\left(\mathrm{NaCl}, \mathrm{KCl}, \mathrm{CaCl}_{2}, \mathrm{MgCl}_{2}, \mathrm{NiCl}_{2}, \mathrm{KBr}\right.$, $\mathrm{KI}, \mathrm{K}_{2} \mathrm{SO}_{4}$ and $\mathrm{KBrO}_{3}$ ) were prepared by considering their respective molecular weight. Samples mixed in prepared solutions were incubated in serological water bath. Vortex mixer (REMI, cyclomixer) was used to mix the sample in the solutions. Solutions were centrifuged in a centrifuge (REMI), and color of the supernatants read in a spectrophotometer (Baush and Lomb, Spectronic 20).

Solutions preparartion: Nine different salts as mentioned above were used to prepare iso-osmotic and hypo-osmotic solutions. Iso-osmotic solutions were prepared in an account of their molecular weights. In order to prepare $50 \%$ hypotonic solutions of the salt solutions, distill water is added in the solution.

Molecular weights of $\mathrm{KCl}, \mathrm{NaCl}, \mathrm{CaCl}_{2}, \mathrm{MgCl}_{2}, \mathrm{NiCl}_{2}, \mathrm{KBrO}_{3}$, $\mathrm{KI}, \mathrm{KBr}, \mathrm{K}_{2} \mathrm{SO}_{4}$ are 74.55, 58.44, 147.02, 203.31, 237.69, $167.0005,166.01,119.01,174.26$ respectively.

When dissolved in water these salts dissociate in smaller ions therefore one molecule of $\mathrm{NaCl}$ gives rise to 2 osmoles, similarly, one molecule of $\mathrm{KCl}, \mathrm{CaCl}_{2}, \mathrm{MgCl}_{2}, \mathrm{NiCl}_{2}, \mathrm{KBrO}_{3}, \mathrm{KI}$, $\mathrm{KBr}$ and $\mathrm{K}_{2} \mathrm{SO}_{4}$ dissociates to give 2 osmoles, 3 osmoles, 3 osmoles, 3 osmoles, 2 osmoles, 2 osmoles, 2 osmoles and 3 osmotic particles respectively.

$1 \mathrm{ml}$ of Isotonic solutions of $\mathrm{NaCl}, \mathrm{KCl}, \mathrm{MgCl}_{2}, \mathrm{CaCl}_{2}$ and $\mathrm{NiCl}_{2}$ and distill water were pipetted in five different Kahn's tube (test-tube). $0.5 \mathrm{ml}$ of isotonic solutions of above five salts were pipetted in five more different test-tubes. $0.5 \mathrm{ml}$ of distill water was added to each of the tubes to prepare $50 \%$ hypotonic salt solutions of five mentioned salts. 20 microlitre of heparinated sample blood was added to each of the isotonic and hypotonic salt solutions and to the distill water and were mixed in a vortex mixer. Sample blood mixed in distill water is used as a control in the study. Sample blood mixed solutions were incubated in a water- bath at 37 degree centigrade for an hour. After an hour, all ten solutions (isotonic and hypotonic solutions of five above mentioned salts) and the control were spun in a centrifuge at $2500 \mathrm{rpm}$ for 7 minutes. 500 microlitre of supernatants from each of the isotonic and hypotonic and control (sample blood mixed in distill water) salt solutions were pipetted into separate cuvettes.

Spectrophotometer was adjusted to $575 \mathrm{~nm}$ to read red colour of hemolysed supernatants. To the 500 microlitre of supernatants of each of the isotonic and hypotonic solutions, distill water was added upto the mark in the cuvettes, absorbance values were noted.

Following the same methods as above, five salts $(\mathrm{KCl}, \mathrm{KBr}$, $\mathrm{KBrO}_{3}, \mathrm{KI}$, and $\mathrm{K}_{2} \mathrm{SO}_{4}$ ) were studied for their hemolytic effect in the red blood cells also.

Guidelines for ethical clearance were satisfied as per rules of Kasturba Hospital Ethics Committee. Waste products and samples disposed satisfying the Healthcare and Environmental management policy, Manipal University.

Sample bloods were collected from five healthy volunteers twice during the study. Subjects on any kind of medications were excluded from the study. Subjects not on medications for deficiency anaemia and without communicable diseases were included after a detail history. $2 \mathrm{ml}$ fresh blood was collected from the subject's antecubital vein under the aseptic precaution in a $5 \mathrm{ml}$ disposable syringe. Collected sample mixed in a heparinised test-tube.

Data was tabulated on MINITAB version 15 and ANOVA was employed for the statistical analysis.

\section{RESULTS}

In order to see the difference in hemolysis among salt solutions, percentage hemolysis was calculated for each of the hypotonic salt solutions. The absorbance value obtained for the supernatant of the blood mixed in distilled water was taken to indicate $100 \%$ hemolysis. This value was used as control. In the numerator was the absorbance read for the hypotonic salt solution and value obtained for control was the denominator. The hemoloysis in list solutions was expressed as percentage of control. The following formula was used for this purpose.

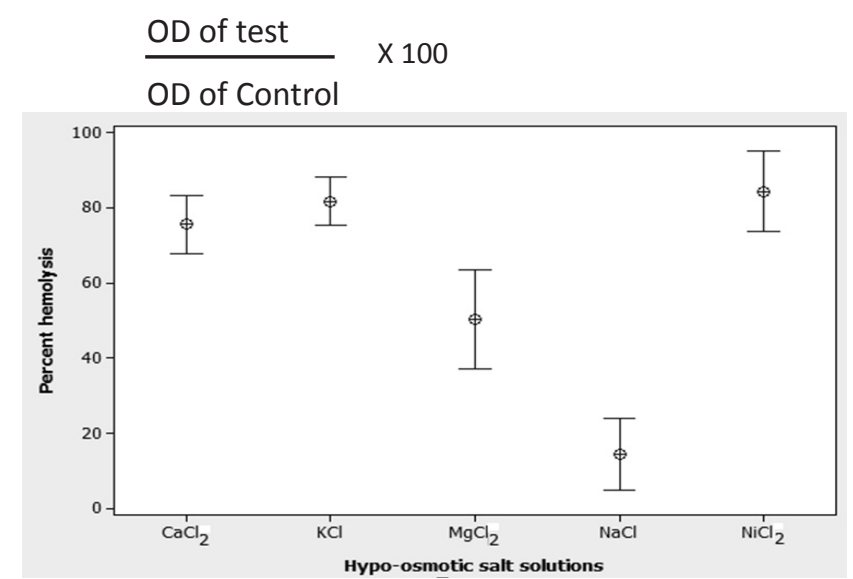

Figure 1. Percentage hemolysis of the hypo-osmotic salt solutions. 


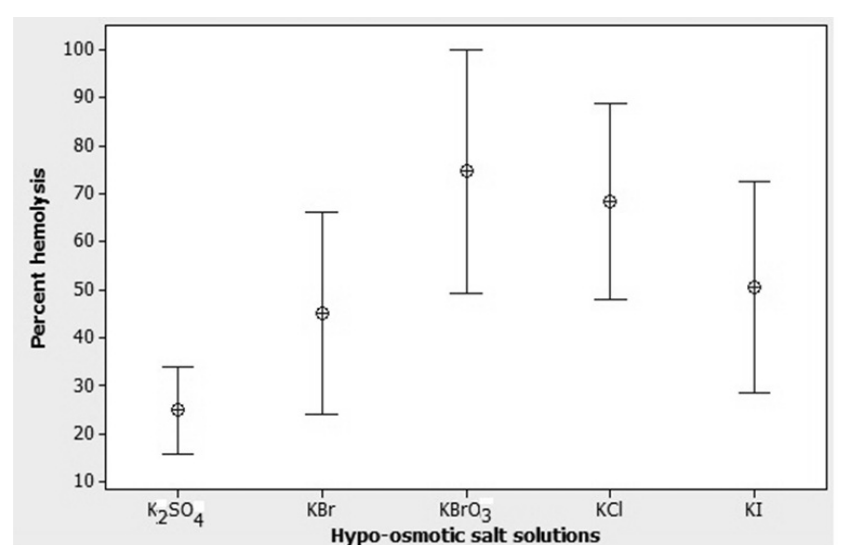

Figure 2. Percentage hemolysis of the hypo-osmotic salt solutions.

Table 1. Readings in five hypotonic hemolysed chloride salt solutions.

\begin{tabular}{lll} 
Salt solutions & Absorbance(OD) & Percentage lysis \\
\hline $\mathrm{NaCl}$ & 0.06 & 15.78 \\
& 0.15 & 26.78 \\
& 0.05 & 12.82 \\
& 0.03 & 07.69 \\
$\mathrm{KCl}$ & 0.03 & 08.57 \\
& 0.32 & 84.21 \\
& 0.49 & 87.50 \\
& 0.30 & 76.92 \\
& 0.33 & 84.61 \\
$\mathrm{MgCl}_{2}$ & 0.28 & 75.67 \\
& 0.12 & 31.57 \\
& 0.30 & 55.35 \\
& 0.20 & 51.28 \\
$\mathrm{CaCl}_{2}$ & 0.21 & 56.41 \\
& 0.21 & 56.75 \\
& 0.27 & 71.05 \\
& 0.48 & 85.71 \\
& 0.30 & 76.92 \\
$\mathrm{NiCl}_{2}$ & 0.29 & 74.35 \\
& 0.26 & 70.27 \\
& 0.28 & 73.68 \\
& 0.46 & 82.10 \\
& 0.32 & 82.05 \\
& 0.38 & 97.43 \\
& 0.32 & 86.48 \\
\hline
\end{tabular}

Data were tabulated on MINITAB version 15. ANOVA was done on the tabulated data. The statistical analysis shows that the effects of hypo-osmotic salt solutions on hemolysis are significantly different with $P$ value, 0.000 among five different chloride salts. Similarly, among five different potassium salts with $P$ value 0.001 hemolysis are found to be significantly different. The data were plotted on confidence interval plot.

The confidence limit of percent hemolysis of $\mathrm{NaCl}$ does not overlap with confidence limit of percent hemolysis of other chloride salt solutions thus the solution has the least percent of hemolysis (figure-1). Among the five potassium salt solutions, hypo-osmotic solution of $\mathrm{K}_{2} \mathrm{SO}_{4}$ shows the least percent hemolysis in the experiment (figure-2). Whereas, percent hemolysis in hypo-osmotic salt solutions of $\mathrm{KBrO}_{3}$ and $\mathrm{NiCl}_{2}$ is highest.
Table 2. Readings in five hypotonic hemolysed potassium salt solutions.

\begin{tabular}{|c|c|c|}
\hline Salt solutions & Absorbance(OD) & Percentage lysis \\
\hline $\mathrm{KCl}$ & $\begin{array}{l}0.26 \\
0.26 \\
0.22 \\
0.22 \\
0.19\end{array}$ & $\begin{array}{l}46.42 \\
81.25 \\
88.00 \\
62.85 \\
63.33\end{array}$ \\
\hline $\mathrm{KBr}$ & $\begin{array}{l}0.19 \\
0.23 \\
0.13 \\
0.12 \\
0.10\end{array}$ & $\begin{array}{l}33.92 \\
71.87 \\
52.00 \\
34.28 \\
33.33\end{array}$ \\
\hline $\mathrm{KBrO}_{3}$ & $\begin{array}{l}0.23 \\
0.25 \\
0.20 \\
0.34 \\
0.23\end{array}$ & $\begin{array}{l}41.07 \\
78.12 \\
80.00 \\
97.14 \\
76.66\end{array}$ \\
\hline $\mathrm{KI}$ & $\begin{array}{l}0.24 \\
0.24 \\
0.07 \\
0.21 \\
0.14\end{array}$ & $\begin{array}{l}42.85 \\
75.00 \\
28.00 \\
60.00 \\
46.66\end{array}$ \\
\hline $\mathrm{K}_{2} \mathrm{SO}_{4}$ & $\begin{array}{l}0.11 \\
0.07 \\
0.08 \\
0.06 \\
0.10\end{array}$ & $\begin{array}{l}19.64 \\
21.87 \\
32.00 \\
17.14 \\
33.33\end{array}$ \\
\hline
\end{tabular}

\section{DISCUSSION}

This study demonstrates that iso-osmotic solutions of $\mathrm{NaCl}$, $\mathrm{KCl}, \mathrm{MgCl}_{2}, \mathrm{CaCl}_{2}, \mathrm{NiCl}_{2}, \mathrm{KBr}, \mathrm{KI}, \mathrm{KBrO}_{3}$ and $\mathrm{K}_{2} \mathrm{SO}_{4}$ do not cause hemolysis. Hypo-osmotic solutions (50\%) of these salts resulted in lysis of the red cells. Red cells in hypotonic $\mathrm{NaCl}$ had least hemolysis among chloride salts.

$\mathrm{K}_{2} \mathrm{SO}_{4}$ among hypo-osmotic potassium salts resulted into least hemolysis. Hemolytic effect of the salt solutions increases as the $\mathrm{pH}$ of the respective salt solutions goes down (acid salt lyses the cells easily due to the lipid peroxidation).

In this study, hypo-osmotic solutions of $\mathrm{KBrO}_{3}$ is found to have greater hemolysis than other salts but this salt failed to show hemolysis in iso-osmotic solution. It became apparent; the salt can lyse the cells when the cells are swollen. If the lysis had occurred only by the acidic peroxidation of the cell membrane, the isotonic solution of the respective salt would have shown the hemolysis, lipid peroxidation requires some time to breach the membrane, thus it seems obvious that red cells in hypotonic solutions are undergoing a morphological change depending on the cations and the anions present in the salt solutions used in the study.

It can be seen from the results that hypo-osmotic solution of $\mathrm{KCl}$ lysed red cells remarkably, as well. The swelling of red cells in hypotonic solution of $\mathrm{KCl}$ result into greater hemolysis due to $\mathrm{K}^{+}$influx into the cells. ${ }^{14} \mathrm{It}$ is found that red cells when swollen in hypotonic $\mathrm{KCl}$, favours the opening of volume sensitive, voltage independent $\mathrm{K}^{+}$channels and further influx of $\mathrm{K}^{+}$ions into these cells hemolyse the 
red cells. The swelling induced by the hypotonic solution perhaps result into chloride interaction with the potassium channels. This leads to opening of volume sensitive channels which allows $\mathrm{K}^{+}$(cation) ions to enter into the cell. Entry of $\mathrm{K}^{+}$ions drag the water molecules into the red cell hence early hemolysis. ${ }^{14}$ The fact that the hypotonic solution of $\mathrm{NaCl}$ did not show hemolysis as much as the hypotonic solution of $\mathrm{KCl}$, favours this finding.

It can be told chloride anion interact with volume sensitive potassium channel and result into greater amount of solution influx, however, this interaction between chloride ions and volume sensitive channels may not be true for $\mathrm{Na}^{+}$ions when red cells are swollen in hypotonic solution of $\mathrm{NaCl}$.

There have been previous indications that volumesensitive, $\mathrm{Cl}$-dependent $\mathrm{K}$ fluxes require ATP. ${ }^{12} \mathrm{Hall}$ and Ellory, who metabolically depleted red cells by a method known to reduce intracellular ATP concentrations to a few micromolar, found that such maneuvers markedly reduced volume sensitive potassium influx. ${ }^{9}$ Higher flux rates through the volume sensitive pathway are found when the cells are separated by density and when the measurements are made in least dense (youngest) fraction. ${ }^{3,12}$

But, in this study we did not separate red cells with respect to density and in this respect; it was similar to the study done by Kaji. ${ }^{14}$

Though, it is seen in our study hemolysis occurs more in $\mathrm{KCl}$ hypotonic solution, but it is not possible to draw definite conclusions regarding the precise nature of $\mathrm{Cl}$ dependent $\mathrm{K}$ transport activated by cell swelling, Kaji and Sachs JR. ${ }^{14,20}$

It is quite clear from the observation that $\mathrm{K}_{2} \mathrm{SO}_{4}$ is least hemolysing among the salts having $\mathrm{K}^{+}$as a cation.

Therefore, it can be inferred that chloride anion may be responsible for $\mathrm{K}^{+}$influx into the red cell which further swells the cell and more water is dragged along with cations $\left(\mathrm{K}^{+}\right)$and leading to early and easy hemolysis of the cell.

The fact that have been found in this study among salts used without potassium $\left(\mathrm{MgCl}_{2}, \mathrm{CaCl}_{2}, \mathrm{NiCl}_{2}\right)$ as cations lysing the red cells gives an impression that chloride anion may even be responsible for influx of cations like $\mathrm{Ca}^{+}, \mathrm{Mg}^{+}$, and $\mathrm{Ni}^{+}$into the red cells.

Similarly, greater hemolysis observed in potassium salt without chloride $\left(\mathrm{KBrO}_{3}\right)$ as anion in the salts used in this study can be due to any cause from oxidative stress to the interaction of $\mathrm{BrO}_{3}{ }^{-}$ion with the volume sensitive potassium channels, which needs further enquiry into the subject to explain with evidence.

$\mathrm{NiCl}_{2}$ is strong oxidant which does not exist in biological form in human body. The quantity used to prepare an isoosmotic (290mosm) solution may not be sufficient enough to produce the membrane peroxidation, therefore massive hemolysis as expected in iso-osmotic preparation of this salt was not found in this study. The massive hemolysis detected in hypo-osmotic solutions of $\mathrm{NiCl}_{2}$ could be the result of entry of nickel through these volume sensitive channels greater in amount than any other ions included in this study.

However, the measurement of ion flux is not performed in this study. Since, the study was performed without the use of specific channel blockers, the influx or efflux of ions either in chloride salts or potassium salts used here cannot detail the precise event that would take place at the red cell membrane. Therefore, this observation is just a study of nature of red cell haemolysis based on comparison of hypotonic salt solutions which cannot unlock the scientific mechanism behind the effect of anions on volume sensitive $\mathrm{K}$ channels. Moreover, observation even cannot assure whether the anions in potassium salts mentioned in this study really cause the volume sensitive potassium channels to open or it is simply the effect of enlarged volume on the red cell membrane that allows more and more water particle to diffuse. Similarly, among the chloride salts used in the study, it can only be hypothesized that perhaps $\mathrm{Cl}$ ions can facilitate the entry of particular cations earlier so that water influx occurs more in particular type of cation; as found in our study, Nickel may be more permeable than $\mathrm{Mg}, \mathrm{Ca}$ and $\mathrm{K}$ ions in the red cell membrane. We are not able to rationalize this study with molecular events to explain the least hemolysis observed in hypotonic $\mathrm{K}_{2} \mathrm{SO}_{4}$ solution and high hemolysis in hypotonic $\mathrm{KBrO}_{3}$ solution.

The interaction of channels and pumps in the red cells with the circulating hormones is an unavoidable fact in vivo. The hormone and red cell membrane interaction also is not considered.

The current study requires further enquiry with better facility to unfold the major events in red cell membrane so that alteration in the red cells morphology and their early destruction for example, mechanism of sickle cell dehydration can be better understood.

\section{CONCLUSION}

Hemolysis in hypo-osmotic solutions indicates that morphological changes that occur in the red cells increase their permeability to various cations leading to their entry into the cells.

The permeability seems to be $\mathrm{NaCl}<\mathrm{MgCl}_{2}<\mathrm{CaCl}_{2}<\mathrm{KCl}=\mathrm{NiCl}_{2}$. Observations on hemolysis with various salts of potassium indicate that $\mathrm{K}_{2} \mathrm{SO}_{4}$ is the least permeable and $\mathrm{KBrO}_{3}$ the most permeable of the anions used.

Our studies signify that anions are capable of altering the permeability of the red cell membrane to potassium, probably through interaction with the volume-sensitive potassium channels. The methods employed in this study to see the effect of various salts on red cell membrane is not supported by advanced technique like patchclamp method and grossly rely on hemolysis achieved in 
hypotonic solutions which is read by spectrophotometer. However, the current study has the implication to see the effects of ions in extracellular fluid in erythrocytes which alters the morphology of the red cells hence the fragility.

\section{REFERENCES}

1. KBeutler E, Lichtman MA, Collar BS, Kipps TJ, Seligsohn U. Williams Hematology. 6th ed. United States: McGraw-Hill; 2001.

2. Brugnara $\mathrm{C}$, Tosteson DC. Cell volume, $\mathrm{K}$ transport, and cell density in human erythrocytes. American Journal of Physiology 1987; 252:C269-C276.

3. Canessa M, Fabry ME, Blumenfeld N, Nagel RL. Volume-stimulated, $\mathrm{Cl}$-dependent $\mathrm{K}$ efflux is highly expressed in young human red cells containing normal hemoglobin or HbS. Journal of Membrane Biology 1987; 97:97-105.

4. Cheng Jen-Tse, Kahn Thomas, Kaji DM. Mechanism of Alteration of Sodium Potassium Pump of Erythrocytes from Patients with Chronic Renal Failure. Journal of Clinical Investigation 1984; 74:1811-20.

5. Dunham PB, Stewart GW, Ellory JC. Chloride-activated passive potassium transport in human erythrocytes. Proceedings of the National Academy of Sciences 1980; 77:1711-5.

6. Dunham PB, Logue PJ. Potassium-chloride cotransport in resealed human red cell ghosts. American Journal of Physiology 1986; 250:C578-C583.

7. Dunham PB, Stewart GW, Ellory JC. Chloride-activated passive potassium transport in human erythrocytes. Proceedings of the National Academy of Science 1980; 77:1711-5.

8. Eveloff JL, Warnock DG. Activation of ion transport systems during cell volume regulation. American Journal of Physiology 1987; 252:F1-F10.

9. Ellory JC, Hall AC, Stewart GW. Volume-sensitive cation fluxes in mammalian red cells. Molecular Physiology 1985; 8:235-46.

10. Gardos G. The function of calcium in the potassium permeability of human erythrocytes. Biochimica et Biophysica Acta 1958; 30:653-4.

11. Grinstein S, Dupre DA, Rothstein A. Volume-induced increase of anion permeability in humanlymphocytes. Journal of General Physiology 1982; 79:849-868.

12. Hall AC, Ellory JC. Evidence for the presence of a volume-sensitive $\mathrm{KC}$ transport in 'young' human red cells. Biochimica et Biophysica Acta 1986; 858:317-320.

13. Hoffman JF. Physiological characteristics of human red blood cell ghosts. Journal of General Physiology 1958; 42:9-28.

14. Kaji D, Amblard J. Volume-sensitive KTransport in Human Erythrocytes. Journal of General Physiology 1986; 88:719-38.

15. Lauf PK, Bauer J. Direct evidence for chloride-dependent volume reduction in macrocytic sheep reticulocytes. Biochemical and Biophysical Research Communications 1987; 144:849-55.

16. Prozansky M, Solomon AK. Regulation of human red cell volume by linked cation fluxes. Journal of Membrane Biology 1972; 10:259-266.

17. Parker JC. Hemolytic action of potassium salts on dog red blood cells. American Journal of Physiology 1983; 244:C313-C317.

18. Sachs JR, Louis GW. The Concentration of Active Potassium Transport in the Human Red Blood Cell. Journal of Clinical Investigation 1967 Jan; 46(1):65-76.

19. Sachs JR. Kinetics of the inhibition of the Na-K pump by external sodium. Journal of Physiology 1977; 264:449-70.

20. Sachs JR. Volume-sensitive $\mathrm{K}$ influx in human red cell ghosts. Journal of General Physiology 1988; 92: 685-711.

21. Wiater LA, Dunham PB. Passive transport of $\mathrm{K}+$ and $\mathrm{Na}+$ in human red blood cells: sulfhydryl binding agents and furosemide. American Journal of Physiology 1983; 245:C348-C356. 